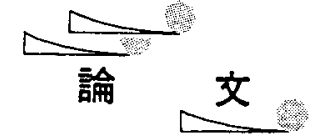

\title{
感温液晶を用いた温度計測の角度による 補正と測定幅の拡大についで*
}

\section{波田 貞之**，亀岡 利行*** \\ Expansion of Thermally Sensitive Range Using Two Different Density Liquid Crystal in Cooperation of Observation Angle Modification}

\author{
Sadayuki Hata and Toshiyuki KAMEOKA
}

\begin{abstract}
Thermo-sensitve liquid crystal display thermal distribution as it changes color according to temperature. By using the developed color image processing technique, spatial thermal information can be obtained. However, modification of the relation between color and temperature is necessary, because the color also depends on an observation angle. The modification is made possible by observing color distribution in the constant temperature field. Liquid crystal is in general inappropriate for measuring a wide thermal range, because its thermo-sensitive range is relatively narrow. Authors expanded this approach to measurement of a wider temperature range using two mixed ratios of liquid crystal with different thermo-sensitive ranges. Applying this approach, thermal plume in a natural convection field is successfully examined.
\end{abstract}

Key words : Liquid crystal, Image processing, Temperature measurement, Natural convection

\section{1. 緒 言}

熱交換器や原子炉などにおける伝熱現象を解明するた めには，複雑な流れがあるため実験的な研究が行われて いる，その熱流動現象を理解するために，空間内全体の 温度場を計測する必要がある，主にこの場合は，熱電対 を大量に測定面に取り付けて行っているが，この温度測 定は流体中に測温体を入れるため，測定面を乱したり， 測定導線から熱の流出入があり温度分布へ影響を与える などの問題点がある。それに対し，感温液晶㲘濁法は， 感温液晶粒子 (直径 $20 \mu \mathrm{m}$ 程度の球形, 比重 $1.01 \sim 1.03$ ) $1 つ 1 つ か ゙$ 温度により色の変化を示すので無数の測定点 が得られ，微粒子のため流れを乱さず，実験対象の温度 分布や挙動の可視化画像が得られる. 可視化画像を力 ラー画像処理を行い色情報を温度情報に換算することで, 空間全体の多点温度測定が可能である ${ }^{1)-3)}$.

感温液晶の呈色は温度による変化だけでなく, 光の入 反射角度によっても变化する. この測定法は可視化画像 の色情報を温度に換算しているので, 観測角度による色 の変化で誤差が発生する。正確な温度を測定するには，

\footnotetext{
* 原稿受付 1998 年 3 月 9 日

** 学生会員 東京電機大学大学院〔現 ·日本製紙侏〕

*** 正会員 東京電機大学
}

色情報と温度情報の他に観測角度の情報を加える必要が ある．従来の方法年ではシート光の角度を変える手法に より, 観測角度における感温液晶の色の変化を求めてい る. そのため, その方法は特別な装置が必要になったり, 観測角度ごとに校正実験を行うため, 非常に手間の掛か る作業であった，そこで，本報告では簡単に観測角度の 情報を加えるために，画像における画素の座標と観測角 度の関係を予求めておいて，観測角度により呈色デー 夕を補正する方法を提案する。

感温液晶の呈色する温度幅は狭く, 温度測定に利用で きる範囲は狭い，呈色する温度幅の全体を利用するため に, ニューラルネットワークを用いて温度測定する研究 が報告されている゙๋. しかし，この温度計測では 1 つの 感温液晶を用いるため, 感温液晶の呈色する温度幅に限 界があり，温度測定できる幅はあまり大きくできない． そこで, 本報告では呈色温度が異なる2つの感温液晶を シリコン油に濃度を変えて懸濁し，兩者を明度の差で識 別して，各々の呈色範囲を利用することで，広い範囲で 温度測定する方法を試みる。また，感温液晶を用いた温 度計測では感温液晶の粒子をトレーサとして温度と速度 の同時計測を行っている2). 本報告において, 加熱体か らの自然対流場の温度分布の解析とともに速度場の解析 も行う。 


\section{2. 可視化実験装置と温度換算方法}

Fig. 1 に，本研究で用いた実験装置の概要を示す．愿 さ $10 \mathrm{~mm}$ の透明アクリル板で作られた油槽 (160×165 $\times 120 \mathrm{~mm}^{3}$ ) には, 作動流体であるシリコン油（信越化 学工業製 $\mathrm{KF}-56$, 比重 $0.9925^{\circ} \mathrm{C}$ ）を入れ, 感温液晶 を懸濁した。空調により実験室内を一定温度に保ち，同 様のアクリル板で作られた水槽 $\left(300 \times 210 \times 300 \mathrm{~mm}^{3}\right)$ は, 恒温水槽から一定温度の水を循環させ, 油槽内の温 度を初期設定する．暗室内において油槽にシート光（ハ ロゲンランプ $1,000 \mathrm{~W}$ 幅 $5 \mathrm{~mm}$ ) を照射することで, 2 次元的に可視化温度場が感温液晶の色彩で示される. 可 視化された面の温度は熱電対で測定する. 可視化画像は CCD メラ (sony CCDVX1 3CCD) で撮影し, 画

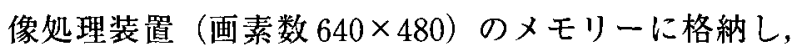
計算機（PC-9801 BX）に記憶する. 温度分布と速度分 布は，記憶された画像を計算機 (CPU Pentium $90 \mathrm{MHz}$, Memory $40 \mathrm{MB}$ ) に移動して，それぞれの值を計算す る. 温度測定は感温液晶の色を認識して温度換算するが, 色情報には色の種類を示す色相を用いた4). 温度分布は 可視化画像の R (赤), $\mathrm{G}$ (緑), $\mathrm{B}$ (青) 值から色相を 算出し, 予め求めておいた色相と温度の関係より求めた.

\section{3．観測角度による誤差の低隇}

\section{1 観測角度の情報を含んだ校正実験}

正確な温度を測定するには，色相と温度の対応関係を 求める校正実験と観测角度による変化量を求める実験が 必要である. 本研究では画像の構成から観測角度による 変化量を同時に測定できる校正実験を行った。

1 枚の画像から温度, 色相と共に観測角度の情報を加 えるために, Fig. 2のように予めCCDカメラと観測面 との距離と実際に撮影できる画像の幅を測定した。 また， 観测角度は中心を $0^{\circ}$ としてシート光側をプラスとした.

感温液晶の呈色は, 等温度場であっても固定された入 射シート光に対し観察する角度 (反射光) により変化す る. 観察画面中央を直角とした場合, 画面の左右の場所 ではそれぞれの位置でそれぞれの角度を持つことにより 呈色が異なる．正しい温度測定のためには，これを補正 する必要がある，なお，入射シート光の水平線に対し上 下方向の位置 (角度)による呈色の相違は認められなかっ た。

画像は画素から成り立っており，画素の位置は座標が つけられている，予め測定した位置関係から，画素の座 標と観測角度の対応関係を求めることで, 画素の位㯰が 観測角度の情報となる。 そのため, Fig. 3 のようにシー ト光と同軸方向の画素の座標を用いて短冊状に分割した. 本研究では测定した可視化画像をプログラム上で画素の 座標から観測角度に分類して校正実験を行った。

\section{2 校正結果}

校正実験では，W 30（日本カプセルクロダクッ製

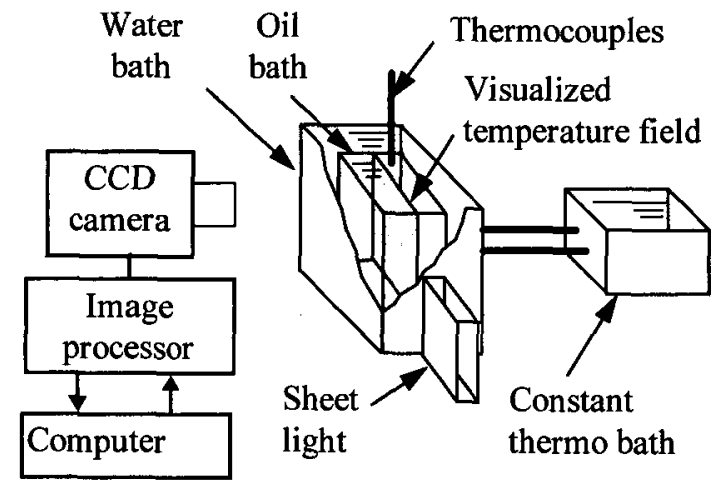

Fig. 1 Experimental apparatus

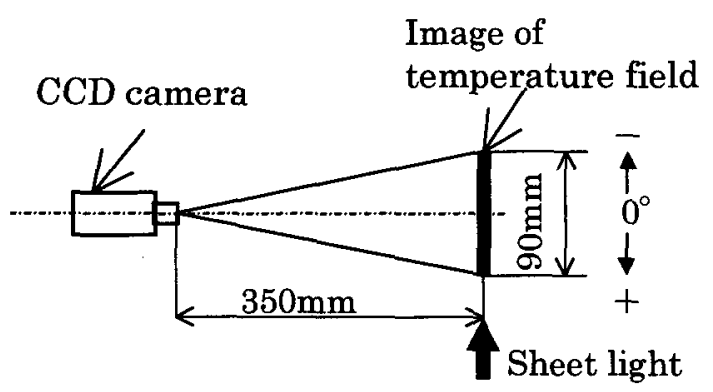

Fig. 2 Observation angle between Sheet light and temperature field

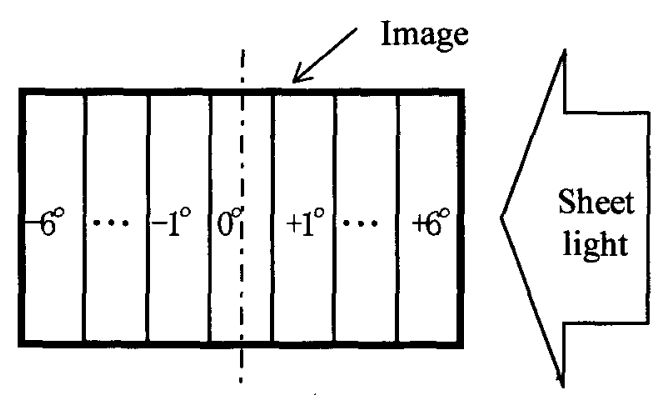

Fig. 3 Division of image

$0.03 \mathrm{wt} \%)$ について, $24^{\circ} \mathrm{C}$ から $28^{\circ} \mathrm{C}$ まで $0.1 \mathrm{~K} こ ゙ と$ に等温度場をスリット幅 $5 \mathrm{~mm}$ で撮影し，観測角度ごと にその温度に対する色相：Hを求めた. Fig. 4 に観測角 度が $0^{\circ}$ の場合と測定画面の両端である $\pm 6^{\circ}$ における 結果を示す．同様に，油槽内にW W 3237 感温液晶（日本 カプセルクロダクッ製 $0.03 \mathrm{wt} \%)$ を䋰濁し， $30.0^{\circ} \mathrm{C}$ から $0.1 \mathrm{~K}$ 刻みで $34.0^{\circ} \mathrm{C}$ までの校正結果を Fig. 5 に示 す.この Fig.4，Fig.5の結果より，温度が上がるに従 い，色相値は赤を示す小さい值から青を示す大きな值に 変化している.この変化している範囲において, 温度と 色相值の換算式を用いることで，可視化画像から温度の 测定ができる．また，色相 0 と 4 [rad］付近では，温 度が変化しても色相値の変化量が少ない，同じ色相にお いて温度幅を持つことになるので, 温度分解能が低いこ とが分かる。 
観測角度について比較すると，色相と温度の関係は， $\pm 6^{\circ}, 0^{\circ}$ のそれぞれで同様な変化の過程を示すが, 変 化の始まる温度と終わる温度が異なっている. Fig. 4 上 り $25.0^{\circ} \mathrm{C}$ では+ $6^{\circ}$ (シート光側) の色相值が黄色を示 す $1[\mathrm{rad}]$ で, $-6 .{ }^{\circ}$ の色相值が赤を示す 0 [rad] で ある。この校正結果より, 感温液晶は同じ温度でも観測 角度を+万方（シート光側）で $0^{\circ}$ (中心部) よりも高 い温度の色彩を示し，逆に一方向で 00 のときょりも低 い温度の呈色を示す．観測角度の補正を行わず温度換算 したならば，画像の色相值が 2 [rad] だとすると, 観 測角度 $6^{\circ}$ では $25.7^{\circ} \mathrm{C}$ を示しており, $-6^{\circ}$ では $26.5^{\circ} \mathrm{C}$ を示している.よって, 画像の両端で温度換算の捠差が $0.8 \mathrm{~K}$ 程度発生する.

本研究では, 観測角度 $1^{\circ}$ ごとに+- $6{ }^{\circ}$ から- $6^{\circ}$ の 温度換算式を求め, 観測角度による誤差を低隇させた。

温度換算式は観測角度 1 ○ごとに求めるかが, 本論文では 代表としてW $30, W 3237$ の $0^{\circ} ， \pm .6 .6^{\circ}$ について示す. W 30 感温液晶

観测角度 : $-6^{\circ}$

$$
\begin{array}{ll}
T=0.586 H+24.904 & (0.241 \leqq H<1.562) \\
T=1.513 H+23.456 & (1.562 \leqq H<2.171) \\
T=0.263 H+26.169 & (2.171 \leqq H \leqq 4.100)
\end{array}
$$

観測角度 : $0^{\circ}$

$$
\begin{array}{ll}
T=0.553 H+24.703 & (0.224 \leqq H<1.702) \\
T=1.961 H+22.307 & (1.702 \leqq H<2.050) \\
T=0.303 H+25.705 & (2.050 \leqq H \leqq 4.082)
\end{array}
$$

観測角度 : $6^{\circ}$

$$
\begin{array}{ll}
T=0.555 H+24.400 & (0.293 \leqq H<1.694) \\
T=1.747 H+22.382 & (1.694 \leqq H<2.131) \\
T=0.287 H+25.493 & (2.131 \leqq H \leqq 4.080)
\end{array}
$$

W 3237 感温液晶

観測角度 : $-6^{\circ}$

$$
\begin{array}{ll}
T=0.367 H+30.618 & (0.327 \leqq H<1.589) \\
T=1.038 H+29.552 & (1.589 \leqq H<2.367) \\
T=0.237 H+31.449 & (2.367 \leqq H \leqq 3.964)
\end{array}
$$

観測角度 : $0^{\circ}$

$$
\begin{array}{ll}
T=0.303 H+30.485 & (0.188 \leqq H<1.531) \\
T=0.937 H+29.515 & (1.531 \leqq H<2.322) \\
T=0.276 H+31.050 & (2.322 \leqq H \leqq 4.081)
\end{array}
$$

観測角度 $: 6^{\circ}$

$$
\begin{array}{ll}
T=0.326 H+30.291 & (0.142 \leqq H<1.773) \\
T=1.414 H+28.363 & (1.773 \leqq H<2.128) \\
T=0.264 H+30.809 & (2.128 \leqq H \leqq 4.031)
\end{array}
$$

観測角度 $1^{\circ}$ ごとに 13 分割して温度換算を行ったため, 観測角度の誤差が $1 / 13$ に狭くなった。 また, Fig. 4 よ り色相値 $2[\mathrm{rad}]$ 付近では傾きが変わるため, 温度へ の換算式は色相の傾き変化が見られる0.5 1.5 [rad]

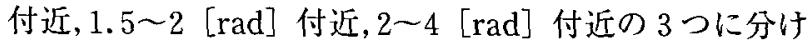
た。

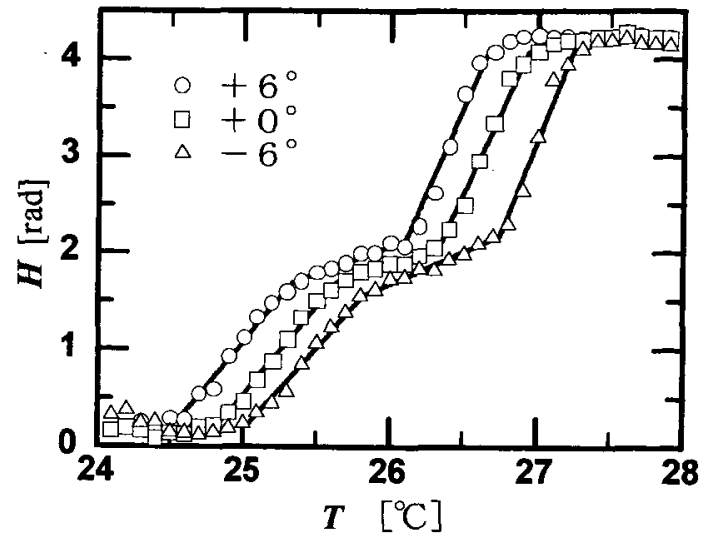

Fig. 4 Relation among hue temperature and angle (W 30)

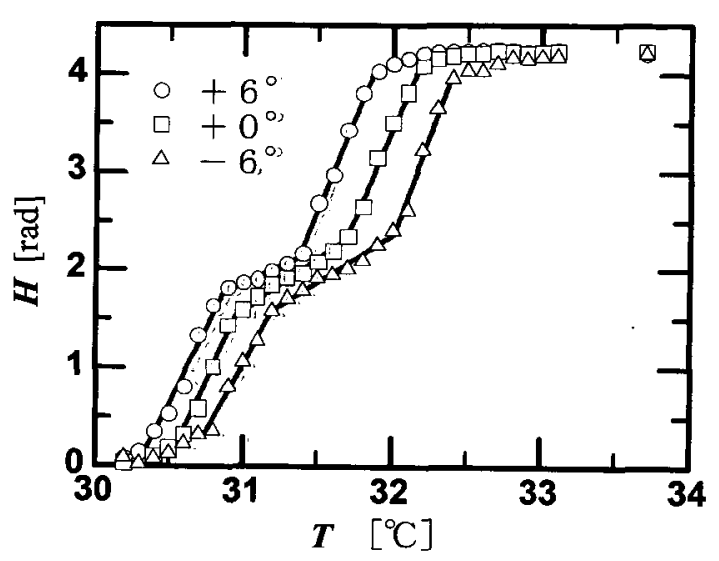

Fig. 5 Relation among hue, temperature and angle (W 3237)

\section{3 自然対流場の温度分布}

加熱体からの自然対流場について熱流の状況を求めた。 温度は観測角度による誤差を低減させるために, Fig. 3 で示した画像の座標で観測角度の情報を加え，その観測 角度に応した温度換算式より求めた。

Fig. 6 は W 30 感温夜晶を用いて, 観測角度による誤 差の補正前と補正後での自然対流場における温度分布を 求めた結果である，加熱体の表面部分に高温で薄い層が 存在すること，上昇流が複雑な形状であり，更にその中 心部分が高温であることが示されている．補正前の画像 では右側のみが高温を示しており，自由表面である上部 に一様に堆積していない。この結果は，伝熱現象を考慮 すると不自然であり，校正結果で述べた観測角度の+方 向で高温を示す結果と一致する. しかし, 補正後の画像 は上部に一様に堆皘が見られ，対流の状況が忠実に示さ れている.よって，観測角度を補正した温度測定の有効 性が示された。 


\section{4. 感温液晶の混濁}

\section{1 感温液晶の区別}

測定温度幅を広げるため, 呈色範囲の異なる 2 つの感 温液晶を混濁した. 2 つ感温液晶を用いる場合は, 温 度換算する前に計算機で両者を見分ける必要がある.

2 つの感温液晶には W 30 と W 3237 を用いた. Fig. 4, Fig. 5 から分かるように, 2つの感温液晶は呈色温度が 異なるが，同じ色相值を示している．そのため，この 2 つを混濁して色相から温度を求めようとすると, 同じ色 相値を持つためどちらの感温液晶で呈色しているかを判 定できない.

感温液晶を区別するために，画像の明るさを示す明度 $(\mathrm{R}+\mathrm{G}+\mathrm{B})$ を用いた. 明度の差を付けるため, W 30 と W 3237 の濃度をそれぞれ $0.01 \mathrm{wt} \%, 0.03 \mathrm{wt} \%$ に設 定し, 明度の差を大きくするため, Fig.7のように画素 $5 \times 5$ の平均值で感温液晶の区別を行った.この領域で 平均值を取れば, W 3237 の濃度が大きいため領域内に 存在する粒子が多く, それだけ明度の差が大きくなる. また, Fig. 7 の領域を用いることで, 感温液晶の呈色む らに対するばらつきを低減させる効果もある. 更に明度 の差を大きくするため, シート光の厚みは $5 \mathrm{~mm}$ から $10 \mathrm{~mm}$ に変更した. 明度の差は W 30 と W 3237 を混濁 した温度成層から求めた. 温度成層は上部を高温, 下部 を低温とすることで対流がなく，温度設定により2つの 感温液晶ですべての発色状態にすることができる.この 温度成層を用いることで, 濃度の違いによる明度の差を 見ることができる.

温度成層における明度と色相の関係を Fig. 8 に示す. 濃度を変えたため, 色相値 $0.5 〜 4$ [rad］の範囲におい て, 明度は W 3237 を示す大きい值，W 30 を示す中間 の值, 背景を示す小さな值の 3 つに区別できる. 色相值 0 と 4 [rad] 付近でW 3237 と W 30 の明度值が重なっ ている. 以上の結果より，感温液晶の判定には，W 30 と W 3237 の重ならない色相の範囲において明度の大き さで条件を設定した.W 30 の条件は色相 0.5 3.8[rad] の範囲で明度 50〜100の大きさで,W 3237 の条件は色 相 $-0.2 \sim 4.5$ [rad］の範囲で明度 100〜220の大きさと した. また, Fig. 8 の内容は, 温度成層なので連続的な 色相値をとることが考えられるが, 2 つの感温液晶を混 ぜたため, 1 つでの感温液晶の呈色している画像の範囲 が狭く, Fig. 7 のうな $5 \times 5$ 画素の平均から求めたた め, 解像度が落ちて連続的な值を示していない.

プログラムでは, Fig. 7 の領域で R, G, B 值の平均 值を求め, 色相と明度を算出して, Fig. 8 の W 30 の条 件と一致していればW 30 であると認識し, W 3237 の 条件と一致していれば W 3237 であると認識する.この ようにして, 温度成層を対象に判別した結果を Fig. 9 に 示す.

Fig. 9 では温度成層上部でW 3237 を，下部で W 30

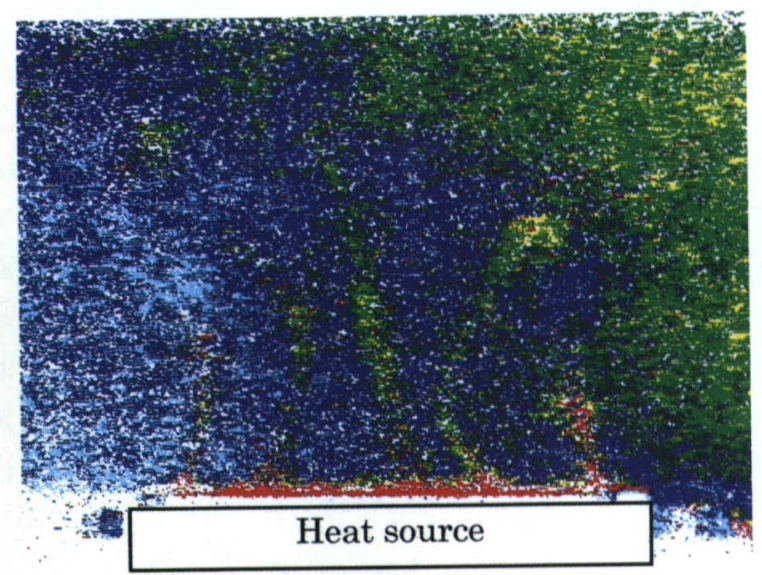

(a) Before modification

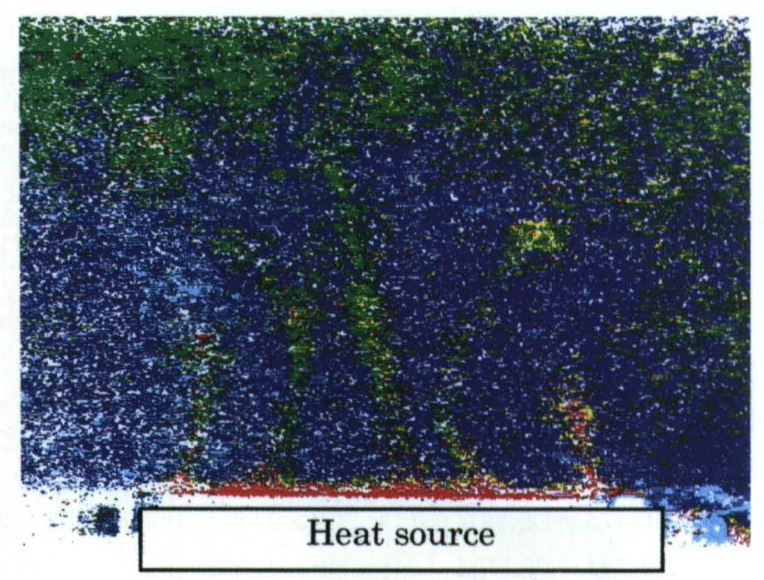

(b) After modification

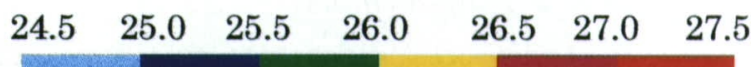

Fig. 6 Temperature distribution and flow patterns with modification of angle(W30)

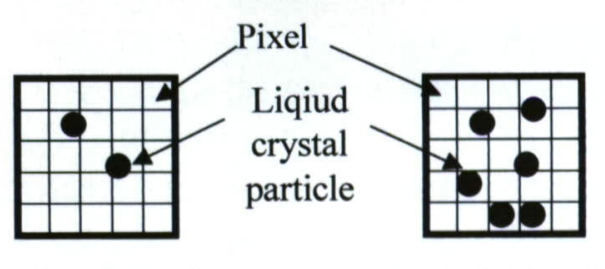

W30 (0.01wt\%)

W3237 (0.03wt\%)

Fig. 7 Distinction of two liqiud crystal

を判定している．W 3237 が高温で，W 30 が低温で呈色 するので，正しい結果を認識できた，また，画像の中央 よりやや上の層で, 白地の部分がある.これは 2 つ感 温液晶が呈色していない温度範囲があるためである.

温度成層であるため, 温度は水平方向に同じ温度であ るが，W 30 を判定している部分が水平でなく左上がり になっている. Fig. 4, Fig.5で示したように，観測角 度により温度と色相の関係が異なり，区別するときに測 定できる色相値の範囲が限られているため, 観測角度に 
より測定可能な温度が異なっている，そのため，西像の 左側（観測角度がー側）では右側に比べ高温側が測定で きるので，W 30 を判定している部分が左上がりになっ ている。

\section{2 温度分布の算出}

2 つの感温液晶を区別できるように実験条件を変更し たため，1つの感温液晶を懸溜した状態と 2 つを混濁し た状態で校正結果を比較した，混濁状態では 1 つの状態 での温度換算式とは異なっていたので，混濁状態で新た に校正実験を行った，混濁状態でも観測角度の補正を行 うために，校正実験では色相と温度の関係と，Fig. 3 の ように画素の座標から観測角度による変化量を求めた。

Fig. 10 は観測角度 $0^{\circ}$ における色相と温度の関係であ る。これより，温度換算式を求めた。温度換算式は 3.2 と同様に観測角度 $1^{\circ}$ ごとに求めるが，本論文では代表 として混濁時の W 30,W 3237 の $0^{\circ}$ について示す.

W 30 感温液晶 (混濁, $0^{\circ}$ )

$$
\begin{array}{ll}
T=0.627 H+24.762 & (0.282 \leqq H<1.655) \\
T=1.125 H+23.938 & (1.655 \leqq H<2.165) \\
T=0.361 H+25.591 & (2.165 \leqq H<3.992)
\end{array}
$$

W 3237 感温液晶 (混濁, $0^{\circ}$ )

$$
\begin{array}{ll}
T=0.449 H+30.664 & (0.195 \leqq H<1.788) \\
T=0.920 H+29.801 & (1.788 \leqq H<2.202) \\
T=0.415 H+30.913 & (2.202 \leqq H<3.957)
\end{array}
$$

混濁状態で温度分布を求めるには，Fig.7の領域で Fig. 8 の条件で区別した後，その領域内で各画素ごとに 色相を求め，区別した結果に基づいて Fig. 10 の結果よ り温度に換算する。ささに, Fig.6, Fig.7の温度分布 と同様に，観測角度による誤差を低減した。この方法で 温度換算すれば，感温液晶の区別には $5 \times 5$ 画素で行う が，温度換算は 1 画素の解像度になる。この方法を用い て自然対流の温度分布を求めた結果を Fig. 11 に示寸。

自然対流において，高温側の感温液晶で測定した温度 範囲の上昇流が，低温側の感温液晶で測定した温度範囲 の層を持ち上げているのが確認できたＷW 30 とW 3237 感温液晶の呈色しない部分では測定できないが, 2 つの 感温液晶の温度域を利用することで, $24.5^{\circ} \mathrm{C}$ から $33.0^{\circ} \mathrm{C}$ までの温度範囲を測定することができた。

$2 つ の$ 感温液晶を用いて温度分布を求める時間は, 計 算機の条件やプログラムによっても異なるが，9 秒程度 であった.

\section{3 混濁状態での流速測定}

前節で解析した自然対流の速度解析を行った。感温液 晶を用いて流速を算出する場合は相関法によって行われ ている2．相関法には相関係数占を用いた方法や簡略化し た輝度差平均法备がある。本研究では計算時間が短く, 正確にベクトルを計算できる輝度差平均法を用いた。相 関計算を実行する小領域のマトリックスを画素 $27 \times 27$ の領域で，輝度情報 $\mathrm{R}+\mathrm{G}+\mathrm{B}$ として算出した速度分布 を Fig. 12 に示す．中心部分に加熱体からの上昇流を捉

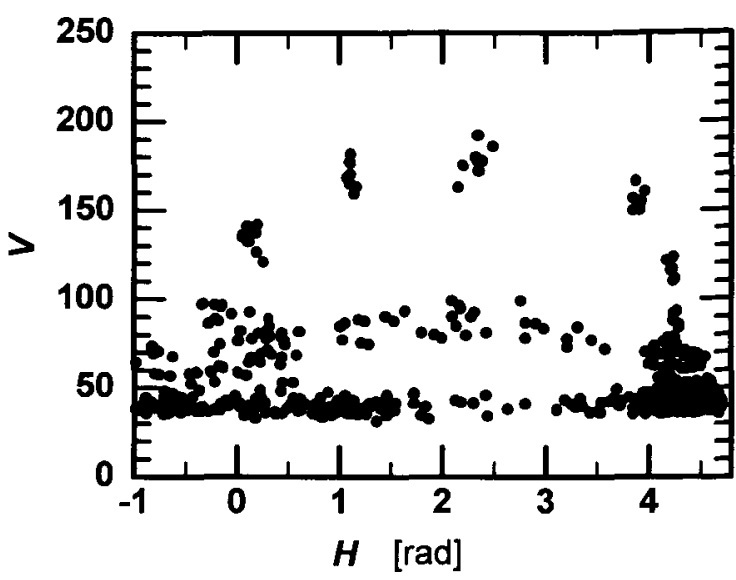

Fig. 8 Relation between value and hue
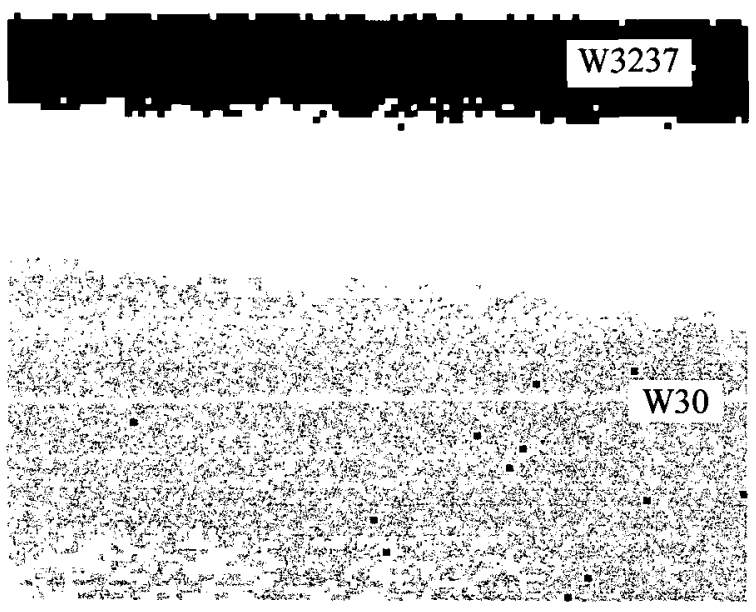

Fig. 9 Result of distinction in thermal stratification field

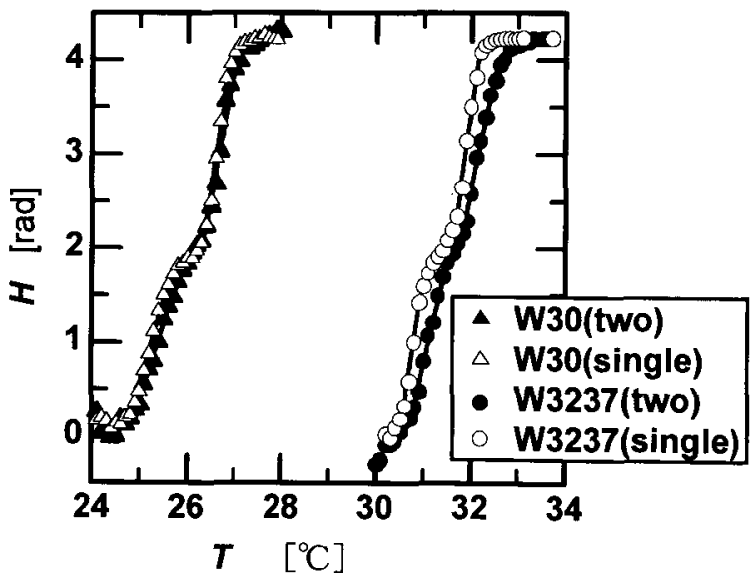

Fig. 10 Relation between hue and temperature with two liquid crystal $\left(0^{\circ}\right)$

えている．しかし，中央よりやや上の層で過䛊ベクトル と思われるような，様々な向きを示しているベクトルが 存在する.この結果は，2つの感温液晶を混ぜているた めこの部分が呈色しておらず，濃度パターンを得ること ができずに判定を間違えたと考えられる。

過誤べクトルをなくすためには, 感温液晶の呈色して 


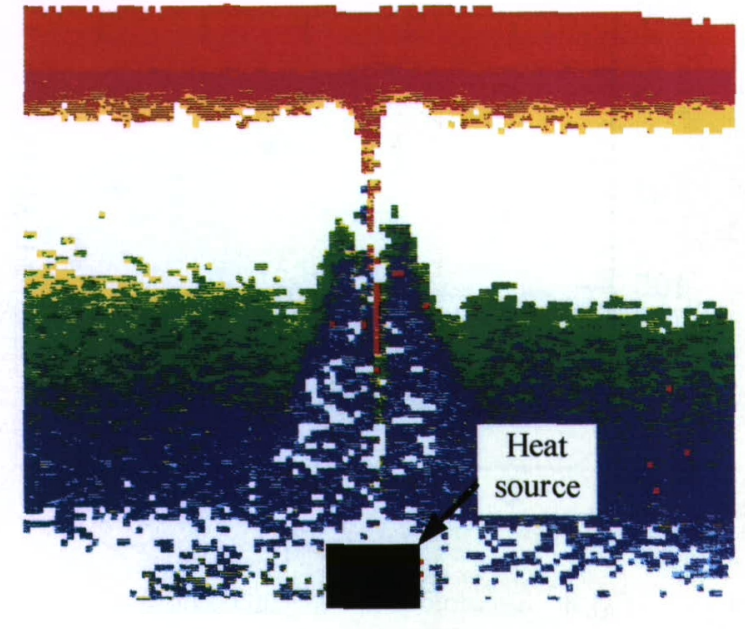

$\begin{array}{lllllll}24.5 & 25.0 & 26.0 & 27.0 & 30.5 & 31.5 & 33.0\end{array}$

Fig. 11 Temperature distribution and flow patterns with mixed liquid crystal

いる領域で処理をすれば良く, 感温液晶の区別ができる 領域が呈色している条件として处理を行った. 感温液晶 の区別をしてW 30, W 3237 のどちらかであれば流速の 計算をして, 条件を満たさなければ計算は行わない.そ の方法で速度分布を求めた結果を Fig. 13 に示す.

この結果を見ると中央よりやや上の層でベクトルがな く, 過誤ベクトルをなくすことができた. そして, 中心 部分で上昇流が測定できている.このように, 感温液晶 の区別する条件を用いて輝度差平均法を用いれば速度べ クトルが求められ, Fig. 11 の温度分布との結果と合わ せれば温度と速度の同時計測が可能である.

計算条件やプログラムによっても異なるが, Fig. 13 の処理時間は 6 分弱程度で, Fig. 12 の処理時間は 9 分 半程度であった. Fig. 13 のような過誤べクトルの除去 を行った場合は, 大幅に計算時間が短縮できた，感温液 晶を区別する時間は, 速度を求める時間に比べて非常に 短く, 呈色している部分のみで速度を求めるため, 速度 を求める点が減少し，計算時間が短縮できた.

\section{5. 結 言}

本研究では校正実験で画素の座標により観測角度の情 報を付け加え, 色相と温度の関係を求め, 同時に観測角 度における色相の変化量を求めた. その結果を利用して, 観測角度による誤差を低隇することができた.

本研究では 2 つの感温液晶を明度で区別して, 2 つの 温度域を利用して測定温度域の拡大を行った。また，混 濁した状態で感温液晶を区別をした条件を用いると，過 誤ベクトルがなく流速を算出することができた．測定温 度幅を広げて, 自然対流の温度分布と速度分布の同時計 測を行った.

なお, 2 つの感温液晶の濃度を変えて懸濁し, それら の明度の美から感温液晶を識別する今回の方法は, 3 つ

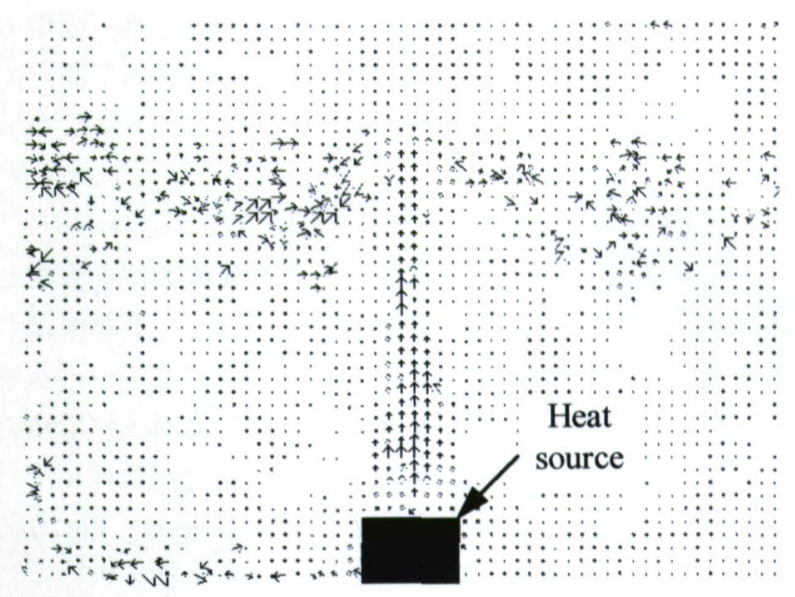

Fig. 12 Velocity vector distribution and flow patterns with two liquid crystal

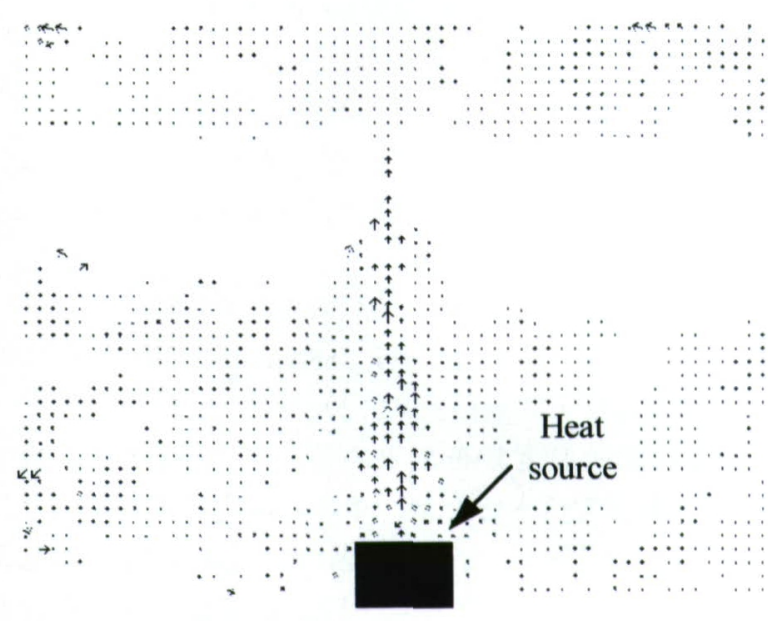

Fig. 13 Velocity vector distribution and flow patterns using condition of distinction

の場合には明確な判定は困難となる．また，動きの大き い流れ場には, 流速の違いにより, 同じ濃度であっても 明度が相違することにより識別が困難となることが考え られる。

\section{参考文献}

1) 秋野: 感温液晶を用いる温度分布の可視化, 熱物性 Vol. 7, No. 4, (1993), 259 265.

2 ）木村, 小澤, 真鍋, 竹中, 高森：感温液晶を用いた温度場と 速度場の同時計測, 計測自動制御学会論文集, Vol. 27, No. 8, (1991), 870 877.

3 ）小澤, 篠木, 木村, 梅川 : 自然対流場の 3 次元画像計測, 可 視化情報, Vol. 17, No. 64, (1997), 41 45.

4 ）清水, 亀岡 : 感温液晶による可視化温度場の自動計測に関す る研究, 可視化情報, Vol. 17, suppl. No.2, (1995), 289 292.

5 ）木村, 高森, 井上：相関を利用した流れ場の速度ベクトル分 布の画像計測 - 円柱後流の変動渦への適用 - , 計測自動制御 学会論文集, Vol. 23, No. 2, (1987),101 107.

6 ）幸, 井上, 加賀, 山口, 吉川：簡易相関処理による煙可視化 像からの気流速度の計測, 流れの可視化, Vol. 8, No. 30, (1988), 293 296. 